\title{
TEKNOLOGI RUMPON UNTUK NELAYAN TRADISIONAL DI KECAMATAN PEMANGKAT KABUPATEN SAMBAS
}

\author{
Saifullah $^{\# 1, \text { Susilawati }}{ }^{* 2}$ \\ 1Prodi Agribisnis Perikanan dan Kelautan, Jurusan Agribisnis, Politeknik Negeri Sambas \\ 2Prodi Agrobisnis, Jurusan Agribisnis, Politeknik Negeri Sambas \\ Email : saifullahtatang@yahoo.co.id
}

\begin{abstract}
ABSTRAK
Selama ini, nelayan tradisional menentukan spot pancing (lokasi penangkapan) hanya dengan mengira-ngira, sehingga tangkapan mereka terbatas. Kondisi cuaca yang tak menentu pada bulanbulan tertentu, terutama rentang bulan November sampai Februari kadang membuat nelayan ragu untuk melaut. Tidak jarang pada masa itu nelayan yang turun kelaut tanpa hasil sama sekali karena tidak bisa melakukan aktivitas penangkapan akibat cuaca buruk sehingga kerugianlah yang mereka peroleh. Pada solusi pertama yakni pelatihan manajemen keuangan, mitra akan dilatih bagaimana melakukan pembukuan keuangan tiap kali melaut dan melakukan penyihan hasil untuk disimpan di bank sebagai cadangan dikala tidak melaut. Solusi kedua yakni pembuatan dan pemasangan rumpon, rumpon merupakan salah satu alat bantu penangkapan untuk meningkatkan hasil tangkapan dimana mempunyai kontruksinya menyerupai pepohonan yang dipasang (ditanam) di suatau tempat di perairan laut. Dalam kegiatan Pengabdian Pada Masyarakat yang merupakan penerapan Ipteks bagi Masyarakat (IbM) ini memerlukan total biaya sebesar Rp. 48.000.000.
\end{abstract}

Keywords— nelayan tradional, Pemangkat, rumpon

\section{PENDAHULUAN}

Mencari dan secara konsisten memproduksi ikan adalah tujuan dari setiap nelayan. Selama ini, nelayan tradisional menentukan spot pancing (lokasi penangkapan) hanya dengan mengira-ngira, sehingga tangkapan mereka terbatas. Tandatanda alam seperti letak gunung (gb.1), keberadaan burung camar (gb.2), arah arus laut dan kedalaman laut menjadi patokan nelayan tradisional dalam memperkirakan lokasi penangkapan. Jelas dengan cara ini keberadaan pasti lokasi ikan tidak dapat terdeteksi dengan jelas sehingga tidak jarang nelayan tradisional pulang dari melaut dengan tangan kosong, tanpa memperoleh hasil maupun hasil tangkapan yang sedikit. Dengan tanpa hasil ini jelas membuat nelayan merugi, karena dalam sekali melaut diperlukan biaya yang tidak sedikit, terutama untuk biaya bahan bakar dan umpan untuk nelayan pancing.

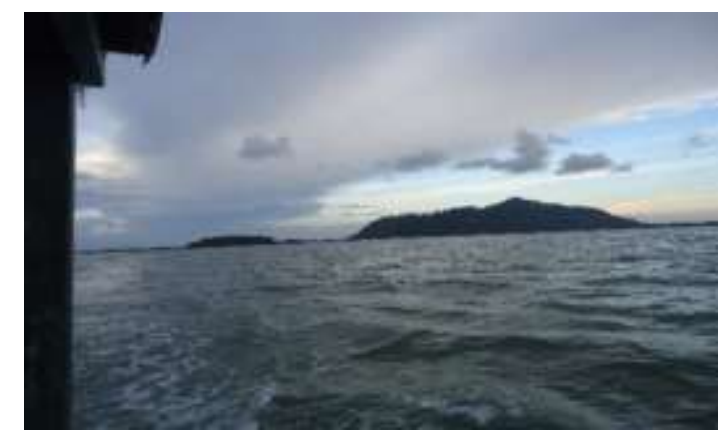

Gambar 1. Letak gunung

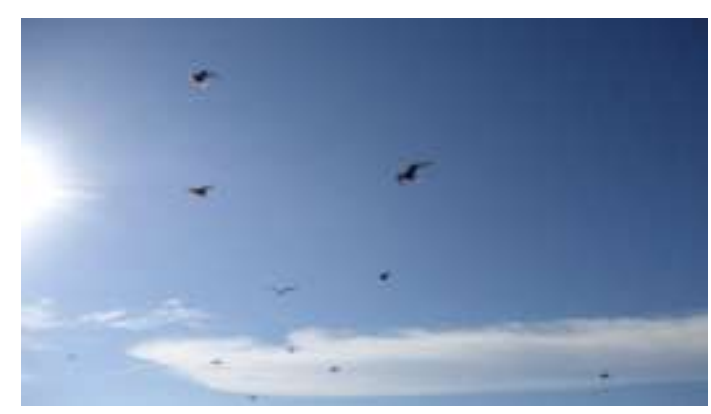

Gambar 2. Burung Camar 
Kondisi cuaca yang tak menentu pada bulanbulan tertentu, terutama rentang bulan November sampai Februari kadang membuat nelayan ragu untuk melaut. Tidak jarang pada masa itu nelayan yang turun kelaut tanpa hasil sama sekali karena tidak bisa melakukan aktivitas penangkapan akibat cuaca buruk sehingga kerugianlah yang mereka peroleh. Ketidakjelasan lokasi gerombolan ikan (spot pancing) yang tepat tiap turun kelaut menjadi masalah utama nelayan tradisional dalam memproduksi ikan.

Ketika musim cuaca buruk tiba dimana ombak dilaut cukup tinggi, yakni sekitar bulan November sampai Februari ( \pm 4 bulan) kebanyakan nelayan terutama mitra lebih memilih tidak melaut. Disaat ini yang akan memperparah kondisi ekonomi mitra dikarenakan tidak pahamnya mitra tentang manajemen keuangan. Budaya menabung saaat panen untuk musim pacaklik masih belum diterapkan oleha nelayan tradisional. Untuk memenuhi kebutuhan hidup seharihari ketika tidak melaut para nelayan ini bekerja serabutan. Tidak sedikit dari nelayan ini yang menjual kapal motor miliknya hanya untuk memenuhi kebutuhan sehari-hari.

Akses insfrastruktur, pendidikan, pengetahuan, SDM, pemanfaatan Teknologi Informasi Kelautan (TIK) masih relatif rendah. Hal ini berpengaruh terhadap sistem penangkapan, pengolahan, dan distribusi produksi ikan di komunitas nelayan. Hadirnya teknologi (TIK) seperti, GPS, Fishfinder, telephone seluler dan internet yang dikonstruksi oleh nilai sosial dan budaya (kearifan lokal) sesuai kebutuhan di lingkungan nelayan mempunyai peluang untuk dapat digunakan sebagai pemberdayaan nelayan tradisional di komunitasnya. Dalam PKM Teknologi Rumpon Untuk Nelayan Tradisional ini akan membantu mitra dalam rangka meningkatkan pendapatan usaha.

\section{SOLUSI DAN TARGET LUARAN}

\subsection{Solusi yang Ditawarkan}

Akses insfrastruktur, pendidikan, pengetahuan, SDM, pemanfaatan Teknologi Informasi Kelautan (TIK) masih relatif rendah. Hal ini berpengaruh terhadap sistem penangkapan, pengolahan, dan distribusi produksi ikan di komunitas nelayan. Hadirnya teknologi (TIK) seperti, GPS, Fishfinder, telephone seluler dan internet yang dikonstruksi oleh nilai sosial dan budaya (kearifan lokal) sesuai kebutuhan di lingkungan nelayan mempunyai peluang untuk dapat digunakan sebagai pemberdayaan nelayan tradisional di komunitasnya.

Dalam PPM Teknologi Rumpon Untuk Nelayan Tradisional ini akan membantu mitra dalam rangka meningkatkan pendapatan usaha. Solusi yang ditawarkan dan disepakati yakni :

1) Pelatihan manajemen keuangan untuk mengatasi musim pacaklik.

2) Pembuatan rumpon dasar.

3) Pemasangan rumpon dilaut dan pengambilan data hasil tangkapan.

\subsection{Target Luaran}

Target luaran yang dihasilkan dari kegiatan Pengabdian Pada Masyarakat ini adalah :

1) Adanya buku catatan produksi dan rekening tabungan di salah satu bank.

2) Empat 16 rumpon (masing-masing mitra 8 rumpon) model balok dengan ukuran lebar $1.5 \mathrm{x}$ panjang $3 \mathrm{x}$ tinggi 2 meter per rumpon dengan bahan : pohon bamboo, pelepah kelapa, ranting kayu bakau, tali pengikat, pemberat dari beton, dan pelampung.

3) Peningkatan hasil tangkapan dengan target minimal $50 \%$.

Solusi dan target luaran secara sistematis dapat dilihat pada tabel 1. Pada solusi pertama yakni pelatihan manajemen keuangan, mitra akan dilatih bagaimana melakukan pembukuan keuangan tiap kali melaut dan melakukan penyihan hasil untuk disimpan di bank sebagai cadangan dikala tidak 
TABEL 1. SOLUSI DAN TARGET LUARAN YANG DISEPAKATI

\begin{tabular}{|l|l|l|}
\hline No. & \multicolumn{1}{|c|}{ Solusi } & \multicolumn{1}{|c|}{ Luaran } \\
\hline 1 & $\begin{array}{l}\text { Pelatihan } \\
\text { Manajemen } \\
\text { Keuangan }\end{array}$ & $\begin{array}{l}\text { Buku catatan } \\
\text { produksi dan Buku } \\
\text { Tabungan }\end{array}$ \\
\hline 2 & Pembuatan Rumpon & $\begin{array}{l}16 \text { buah rumpon } \\
\text { dengan ukuran 1.5 } \\
\text { x } 3 \text { 2 meter }\end{array}$ \\
\hline 3 & $\begin{array}{l}\text { Pemasangan dan } \\
\text { rumpon } \\
\text { pengambilan data }\end{array}$ & $\begin{array}{l}\text { Peningkatan hasil } \\
\text { tangkapan minimal } \\
50 \% .\end{array}$ \\
\hline
\end{tabular}

Solusi kedua yakni pembuatan rumpon, rumpon merupakan salah satu alat bantu penangkapan untuk meningkatkan hasil tangkapan dimana mempunyai kontruksinya menyerupai pepohonan yang dipasang (ditanam) di suatau tempat di perairan laut yang berfungsi sebagai tempat berlindung, mencarai makan, memijah, dan berkumpulnya ikan. Diutara Pulau Jawa telah lama mengenal rumpon untuk memikat ikan agar berkumpul di sekitar rumpon, sehingga memudahkan penangkapan (Suwarsih, 2012). Dalam jangka waktu 4 bulan yaitu Bulan Januari April 2012 pemasangan rumpon saat musim barat meningkatkan hasil tangkapan sebesar 24\%. (Kurniawan dkk, 2013). Penggunaan rumpon meningkatkan produksi usaha dan hari operasi per trip lebih pendek sehingga biaya operasional kapal lebih ekonomis. ( Handayani, 2013). Pengusul bersama-sama mitra membuat rumpon dengan ukuran 1.5 x 3 x 2 meter dengan bahan : pohon bamboo, pelepah kelapa, ranting bakau, tali pengikat, pemberat dari beton dan pelampung. Jumlah rumpon yang akan dibuat sebanyak 15 unit, masing-masing mitra mendapatkan 7 - 8 unit rumpon. Rancangan bentuk rumpon yang disepakati akan dibuat seperti pada gambar 3.

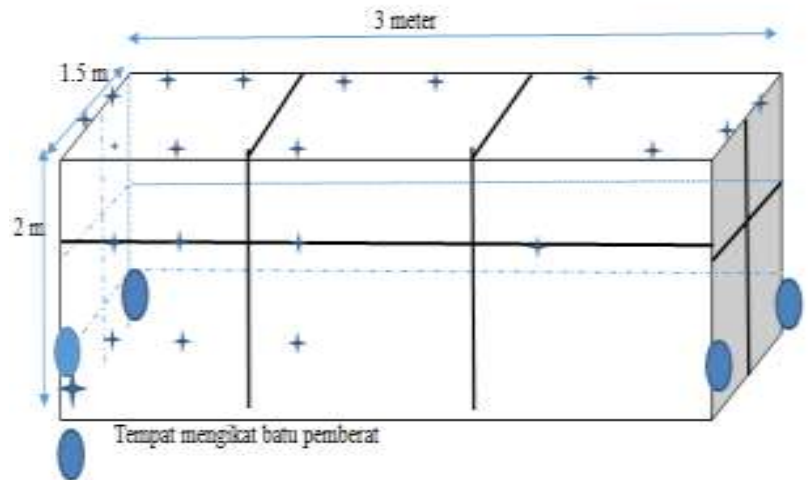

Gambar 3. Rancangan bentuk rumpon yang akan dibuat

Solusi yang ketiga adalah pemasangan rumpon. Rumpon yang dipasang diperkirakan berjarak 12 mil dari pelabuhan perikanan pemangkat. Teknik pemasangan rumpon, tiap mitra akan dipasang dua rumpon yang berdekatan dengan jarak \pm 60 meter arah utara selatan. Arah utara selatan ini sesuai dengan arah arus yang terjadi di perairan Sambas, yakni arus akan bergerak kearah utara dan selatan ketika terjadi pasang surut. Skema pemasangan rumpon dan posisi jangkar kapal dapat dilihat pada gambar 4 .
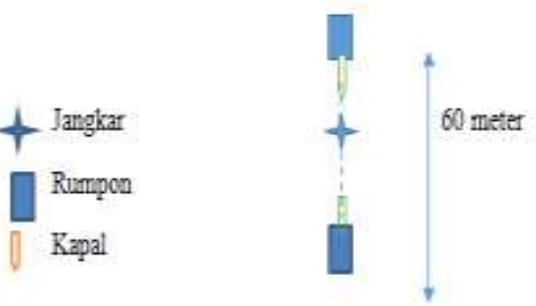

Gambar 4. Skema pemasangan rumpon 
Rencana capaian luaran tahunan dapat dilihat pada tabel 2 dibawah ini.

TABEL 2. RENCANA TARGET CAPAIAN LUARAN

\begin{tabular}{|c|l|c|}
\hline No & \multicolumn{1}{|c|}{ Jenis Luaran } & $\begin{array}{c}\text { Indikator } \\
\text { Capaian }\end{array}$ \\
\hline 1 & Publikasi ilmiah di jurnal/prosiding & Published \\
\hline 2 & $\begin{array}{l}\text { Publikasi pada media masa } \\
\text { (cetak/elektronik) }\end{array}$ & Ada \\
\hline 3 & $\begin{array}{l}\text { Peningkatan omzet pada mitra yang } \\
\text { bergerak dalam bidang ekonomi }\end{array}$ & Ada \\
\hline 4 & Peningkatan kuantitas dan kualitas & Ada \\
\hline 5 & $\begin{array}{l}\text { Peningkatan pemahaman dan } \\
\text { ketrampilan masyarakat }\end{array}$ & Ada \\
\hline 6 & $\begin{array}{l}\text { Peningkatan ketentraman /kesehatan } \\
\text { masyarakat (mitra masyarakat } \\
\text { 2) }\end{array}$ & Ada \\
\hline 7 & $\begin{array}{l}\text { Jasa, model, rekayasa sosial, sistem, } \\
\text { produk/barang }\end{array}$ & $\begin{array}{l}\text { Produk dan } \\
\text { penerapan }\end{array}$ \\
\hline 8 & $\begin{array}{l}\text { Hak kekayaan intelektual (paten, paten } \\
\text { sederhana, hak cipta, merek dagang, } \\
\text { rahasia dagang, desain produk } \\
\text { industri, perlindungan varietas } \\
\text { tanaman, perlindungan topografi) }\end{array}$ & Tidak ada \\
\hline 9 & \begin{tabular}{l} 
Buku ajar \\
\hline
\end{tabular} & Ada \\
\hline
\end{tabular}

Pada PKM ini rencana target capaian luaran dari hasil kegiatan akan dipublikasikan pada jurnal ilmiah nasional dan media massa setempat. Diharapkan manfaat yang nyata bagi mitra berupa peningkatan pendapatan mitra, peningkatan kualitas hasil tangkapan dan peningkatan pemahaman dan ketrampilan mitra. Hasil kegiatan PKM juga diharapkan bisa menjadi bahan ajar atau draf buku ajar untuk mata kuliah Penangkapan.

\section{METODE PELAKSANAAN}

Dari hasil dialog dan survey lapangan pengusul bersama mitra mengidentifikasi kegiatan yang diperlukan untuk mengatasi persoalan yang dihadapi mitra. Dari hasil identifikasi persoalan, maka disepakati tahapan kegiatan dan metode pendekatan yang akan dilakukan selama pelaksanaan program Pengabdian Kepada Masyarakat (PKM) adalah :

1) Pelatihan manajemen keuangan, Pada kegiatan ini pelaksana memberikan tutorial dan dilanjutkan dengan diskusi tentang bagaimana memenej keuangan dan dituangkan didalam buku catatan dan bagaimana melakukan penyisihan untuk disimpan di Bank.

2) Pembuatan rumpon, Pelaksana bersamasama mitra menyiapkan bahan, membuat gambar dan merakit rumpon. Rumpon yang dihasilkan 16 unit, masing-masing mitra mendapatkan 8 unit rumpon.

3) Pemasangan rumpon dan pengambilan data, Pemasangan rumpon menggunakan kapal motor milik mitra dengan cara 8 rumpon satu spot pancing sesuai dengan gambar 4. Lokasi yang dipilih untuk memasang rumpon adalah lokasi yang berkarang dan berdasarkan pengalaman mitra dan di dengan bantuan alat navigasi berupa GPS dan fish finder.

\section{TABEL 3. RENCANA KEGIATAN, METODE DAN} LUARAN YANG DISEPAKATI

\begin{tabular}{|l|l|l|l|l|}
\hline No & \multicolumn{1}{|c|}{$\begin{array}{l}\text { Rencana } \\
\text { Kegiatan }\end{array}$} & Metode & $\begin{array}{l}\text { Jumlah } \\
\text { kegiatan }\end{array}$ & Luaran \\
\hline 1. & $\begin{array}{l}\text { Pelatihan } \\
\text { manajemen } \\
\text { keuangan } \\
\text {, Diskusi }\end{array}$ & $\begin{array}{l}\text { Tutorial } \\
\text { kegiatan }\end{array}$ & $\begin{array}{l}\text { Buku } \\
\text { Catatan } \\
\text { Produksi } \\
\text { dan Buku } \\
\text { Rekening }\end{array}$ \\
\hline 2. & $\begin{array}{l}\text { Pembuatan } \\
\text { Rumpon }\end{array}$ & Praktek & $\begin{array}{l}4 \text { kali } \\
\text { kegiatan }\end{array}$ & $\begin{array}{l}15 \text { unit } \\
\text { Rumpon }\end{array}$ \\
\hline 3. & $\begin{array}{l}\text { Pemasanga } \\
\text { n Rumpon }\end{array}$ & Praktek & $\begin{array}{l}10 \text { kali } \\
\text { kegiatan }\end{array}$ & $\begin{array}{l}\text { Koordina } \\
\text { t Rumpon } \\
\text { (4 titik) }\end{array}$ \\
\hline 4. & $\begin{array}{l}\text { Pengambila } \\
\text { n data }\end{array}$ & Praktek & $\begin{array}{l}10 \text { kali } \\
\text { kegiatan }\end{array}$ & $\begin{array}{l}\text { Peningkat } \\
\text { an } \\
\text { Produksi }\end{array}$ \\
\hline
\end{tabular}

Rencana kegiatan, metode dan luaran yang telah disepakati antara pengusul dan mitra dapat dilihat pada tabel 3. Kegiatan direncanakan sebanyak 26 kali dengan metode tutorial, diskusi dan praktek.

\section{HASIL DAN PEMBAHASAN}

\subsection{Hasil dan Luaran Yang Dicapai}

Pelaksanaan kegiatan pelatihan pembuatan rumpon di Kecamatan Pemangkat 
pada kelompok nelayan tradisional terkait erat pada Politeknik Negeri Sambas pada jurusan agrobisnis prodi agribisnis perikanan. Hal ini dilandasi oleh kualifikasi yang dimiliki oleh tim pelaksanaan yang berasal dari pendidikan perikanan.

Pada pembuatan rumpon ini tim pelaksana bekerja sama dengan mitra yaitu pada kelompok nelayan tradisional yang ada di Kecamatan Pemangkat. Di tempat ini tim pelaksanaan menyiapkan segala keperluan untuk pelatihan pembuatan rumpon, secara garis besar komponen tersebut adalah pelampung (float), tali (rope), pemikat (atractor), pemberat (sinker). Secara ringkas, pelaksanaan pelatihan ini dipaparkan berdasarkan pembuatan komponen rumpon yang dilaksanakan.

\subsection{Proses Pembuatan Pemberat Rumpon}

Pembuatan pemberat rumpon dari bahan utama beton yang dicor kedalam karung sehingga nantinya rumpon tidak hanyut terbawa oleh arus ataupun ombak. Dalam pelatihan pembuatan pemberat rumpon ini, dipilih pemberat dari beton yang dicor adalah untuk memenuhi syarat-syarat seperti: Bahannya murah, kuat dan mudah diperoleh, Massa jenisnya besar, permukaannya tidak licin dan dapat mencengkaram. Adapun proses pembuatan pemberat rumpon lebih jelasnya dapat dilihat pada gambar dibawah ini.

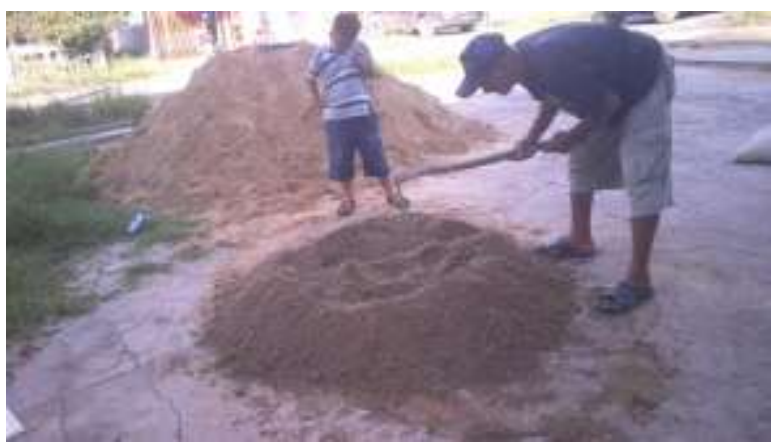

Gambar 5. Proses Pembuatan Pemberat Rumpon

Kegiatan PKM bersama mitra membuat media pemberat rumpon yang dilakukan pada nelayan tradisional di Pemangkat. Proses pembuatan media rumpon dilakukan bersama-sama mitra. Berdasarkan pada gambar 5 diatas menunjukkan bahwa proses pembuatan rumpon yang dilakukan oleh mitra. Ada pun bahan yang digunakan dalam proses pembuatan rumpon yaitu semen, pasir dan batu. Pertama-tama dilakukan pencampuran dua bahan yaitu semen dan pasir, setelah bahan tersebut sudah tercampur kemudian ditambakan batu, kemudian di aduk sampai merata. Dari ketiga bahan tersebut setelah tercampur dengan merata kemudian dicamur air secukupnya sehingga bahan tersebut mudah melakukan pencetakan. Adapun tahapan pencetakan dan batu pemberat rumpon dapat dilihat pada gambar 5, 6 dan 7 dibawah ini.

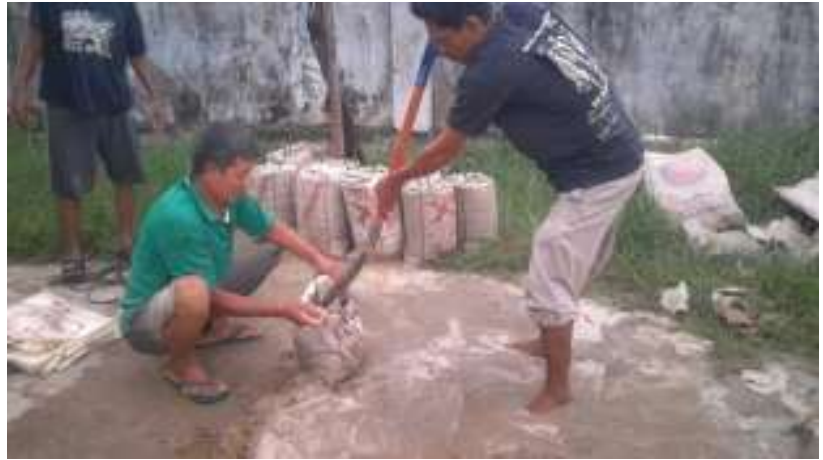

Gambar 6. Proses Pencetakan Batu Pemberat Rumpon

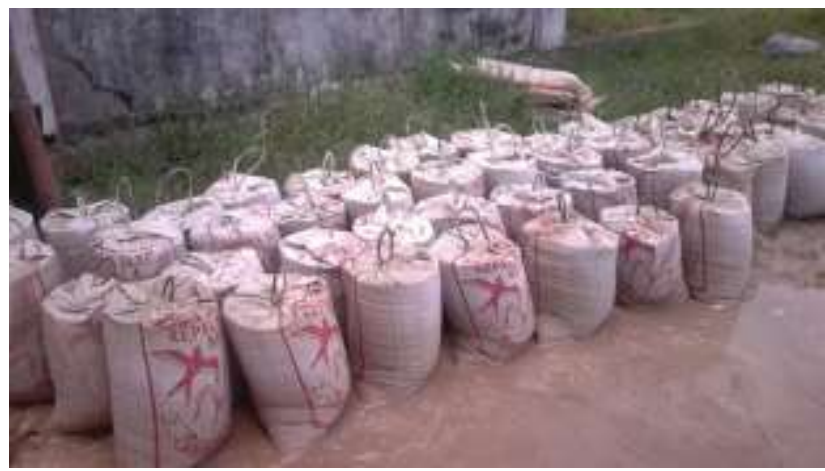

Gambar 7. Pemberat Rumpon yang telah jadi dicetak 


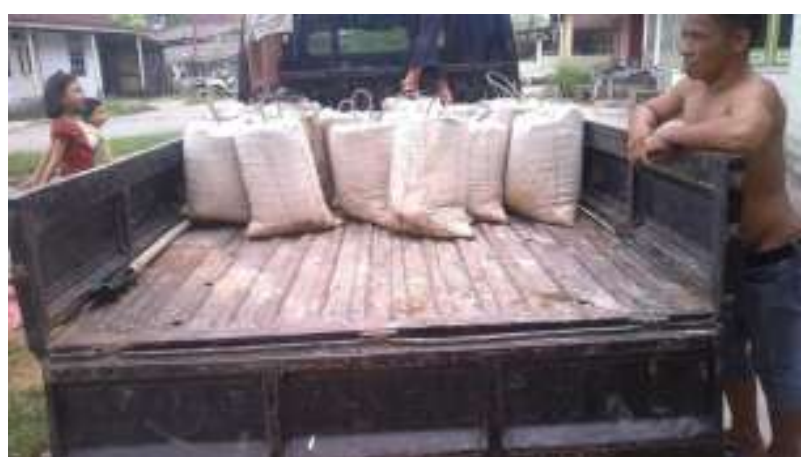

Gambar 8. Proses Pengangkutan Pemberat Rumpon

Batu pemberat rumpon yang telah jadi di buat oleh mitra di angkut kedermaga. Proses pengangkutan batu pemberat rumpon dilakukan dengan menggunakan mobil. Adapun proses pengangkutan batu pemberat rumpon dapat dilihat pada gambar 8 diatas.

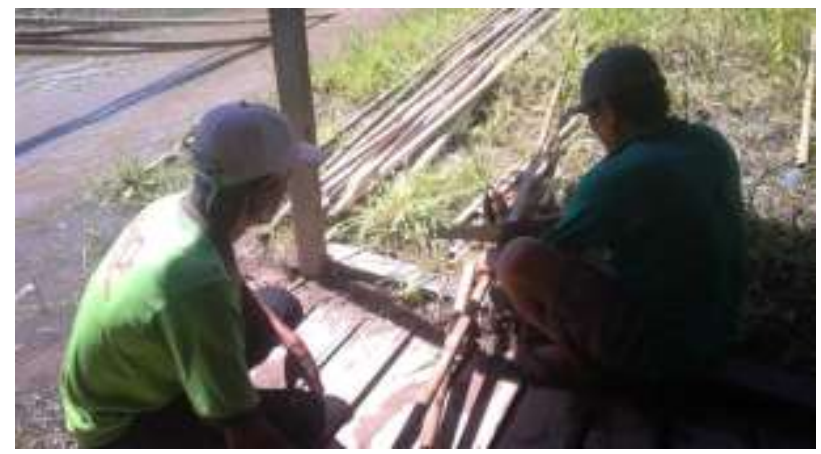

Gambar 9. Proses Pemotong Bambu

Proses pemotongan bambu untuk pembuatan rangka rumpon dilakukan oleh kedua mitra. Sebelum melakukan pemotongan bambu diukur terlebih dahulu, sesuai dengan ukuran rumpon yang akan dibuat. Proses pembuatan rumpon dapat dilihat pada gambar 9, 10 dan 11 .

\subsection{Pimikat Rumpon}

Pembuatan pemikat yang terdiri dari susunan yang berbentuk vertikal maupun horizontal, pemikat ini bertujuan untuk menarik ikan-ikan agar tertarik untuk datang dan tinggal di rumpon yang kita buat nantinya. Pembuatan pemikat ini dapat dimanfaatkan bahan bekas yang tersedia. Dimana selain sebagai pemikat juga dapat menjadi rumah dan melindungi ikan dari serangan dari ikan-ikan lainnya yang jadi pemangsanya atau pun dari pergerakan arus dan ombak laut. Tali yang menghubungkan pemberat dan pelampung pada jarak tertentu disiapkan daun nyiur yang masih melekat pada pelepahnya.

Adapun beberapa persyaratan yang harus dimiliki oleh pemikat yang dapat digunakan adalah; mempunyai daya pikat yang baik terhadap ikan, mempunyai bentuk seperti posisi potongan vertikal dengan arah ke bawah, tahan lama, melindungi ikan-ikan kecil dan terbuat dari bahan yang kuat, tahan lama dan murah. Adapun proses perakitan dan pemasangan rumpon lebih jelasnya dapat dilihat pada gambar dibawah ini;

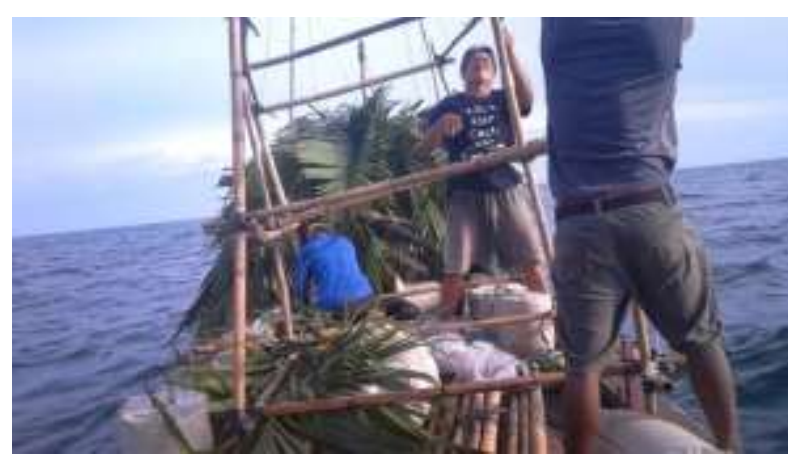

Gambar 10. Proses Pemasangan Rangka Rumpon

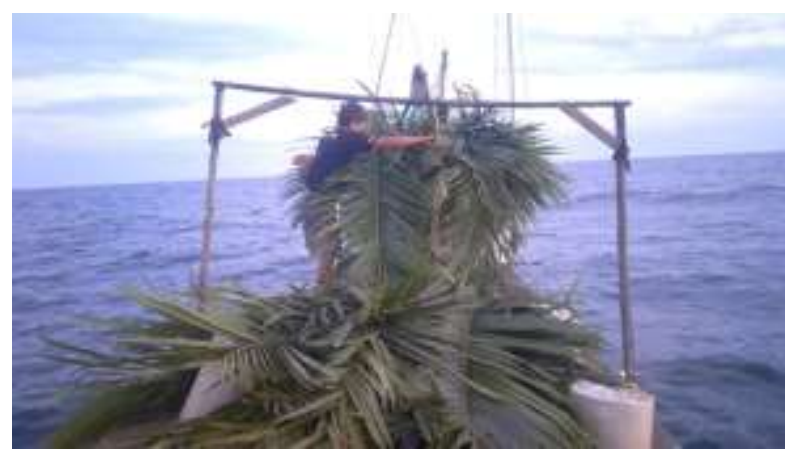

Gambar 11. Pelepah Kelapa Untuk Media Rumpon 


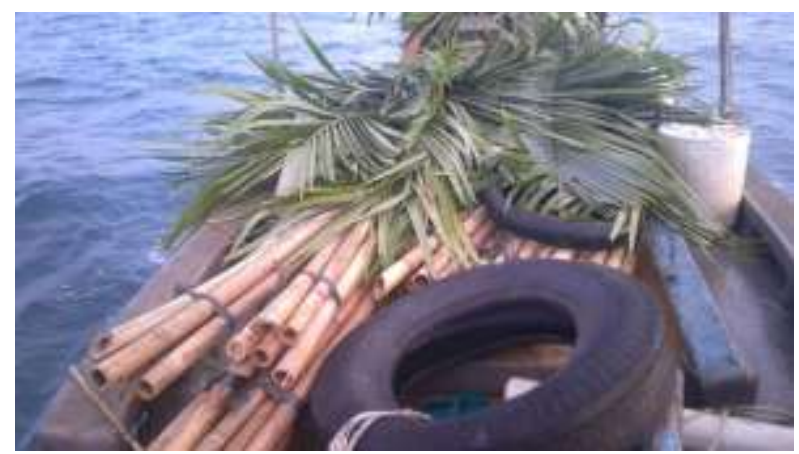

Gambar 12. Bahan Pembuat Rumpon

\subsection{Tali Temali}

Tali digunakan untuk menghubungkan pemberat dengan pelampung, selain itu tali menjadi tempat di ikatnya pemikat. Panjang tali bervariasi, tetapi pada umumnya adalah 1,5 kali kedalaman laut tempat rumpon tersebut ditanam/ditempatkan. Melihat pentingnya tali dalam suatu rompon, maka adapun syarat-syarat yang harus dimiliki oleh tali yang digunakan adalah;

1) Terbuat dari bahan yang kuat dan tidak mudah busuk

2) Harga relatif murah

3) Mempunyai daya apung yang cukup untuk mencegah gesekan terhadap bendan-benda lainnya dan terhadap arus

4) Tidak bersimpil (less knot)

Adapun penanda rumpon yang telah terikat tali lebih jelasnya dapat dilihat pada gambar dibawah ini;

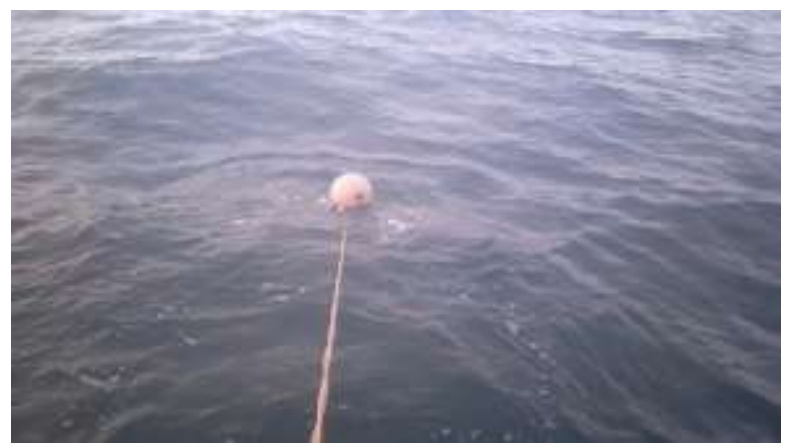

Gambar 13. Pelampung Rumpon yang telah dipasang.

Pemasangan rumpon dilakukan bersama-sama dengan nelayan. Pemasangan rumpon dilakukan di perairan laut pemangkat, dengan jarak kurah lebih 12 mil dari pantai. Sebelum melakukan pemasangan, rumpon diberi penanda berupa pelampung. Pelampung digunakan sebagai penanda letak rumpon, sehingga memudahkan nelayan untuk melakukan pengecekan lokasi yang telah dipasang rumpon.

\subsection{Pelatihan Instalasi Fish Finder pada Kapal Tangkap Nelayan}

Pelatihan fish finder bertujuan untuk mempermudah nelayan menentukan titik pemasangan dan pengecekkan rumpon yang telah dipasang. Nelayan tradisional yang menjadi mitra pada kegiatan ini, belum bisa cara menginstal fish finder pada kapal tangkap sehingga perlu diberi pelatihan. Komponen utama dalam pengoperasian fish finder ada tiga; monitor, sonar dan baterai. Walaupun tampak sederhana, kalau salah pasang bias fatal. Tiga komponen tersebut saling terhubung dengan menggunakan kabel dan konektor yang telah tersedia. Nelayan diajarkan membaca kode-kode yang terdapat pada monitor, konektor dan baterai berikut cara menghubungkannya, seperti terlihat pada gambar 14 dan 15.

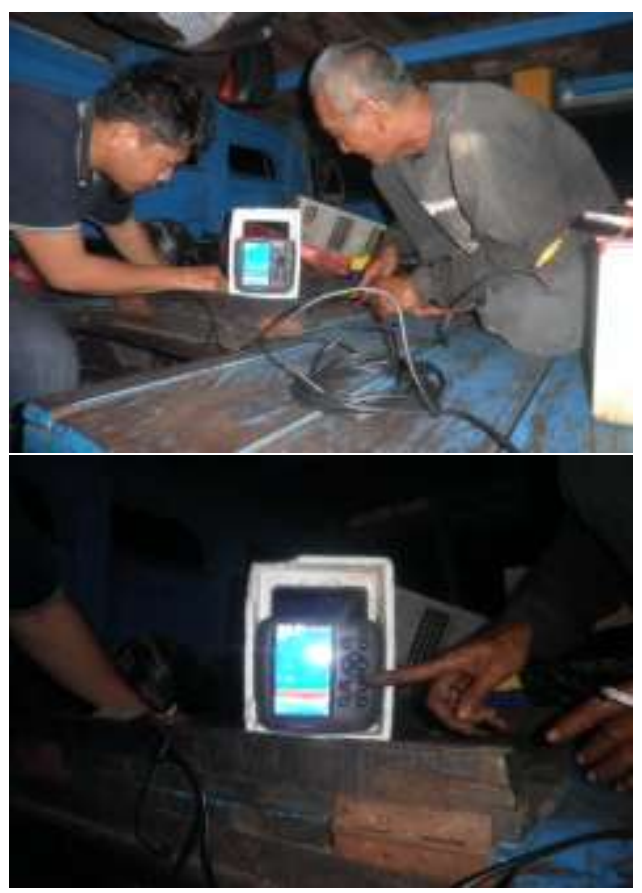

Gambar 14. Instalasi fish finder Gambar. 15. Mempelajari fungsi tombol 
Pada gambar 14 dan 15 terlihat pelaksana dan mitra bersama-sama menginstal fish finder, dari mulai pemasangan sonar, menghubungkan konektor sonar dan konektor baterai, sampai mempelajari masing-masing fungsi tombol.

\subsection{Pelatihan Pengoperasian Fish Finder}

Setelah fish finder terinstal dengan sempurna, Pengoperasian fish finder dimulai dengan menekan tombol power, dilanjutkan dengan pengaturan menu utama, yakni zoom, gain, dept, dan setup. Mitra diajarkan caracara mengoperasikan fish finder, terutama cara membaca tombol dan maksud dari fiturfitur yang tertera pada fish finder. Cara kerja fish finder dan tampilan fish finder juga diajarkan pada mitra, berikut gambar ikan yang terekam pada monitar fish finder dan hasil tangkapan diperlihatkan pada gambar 16 dan 17.

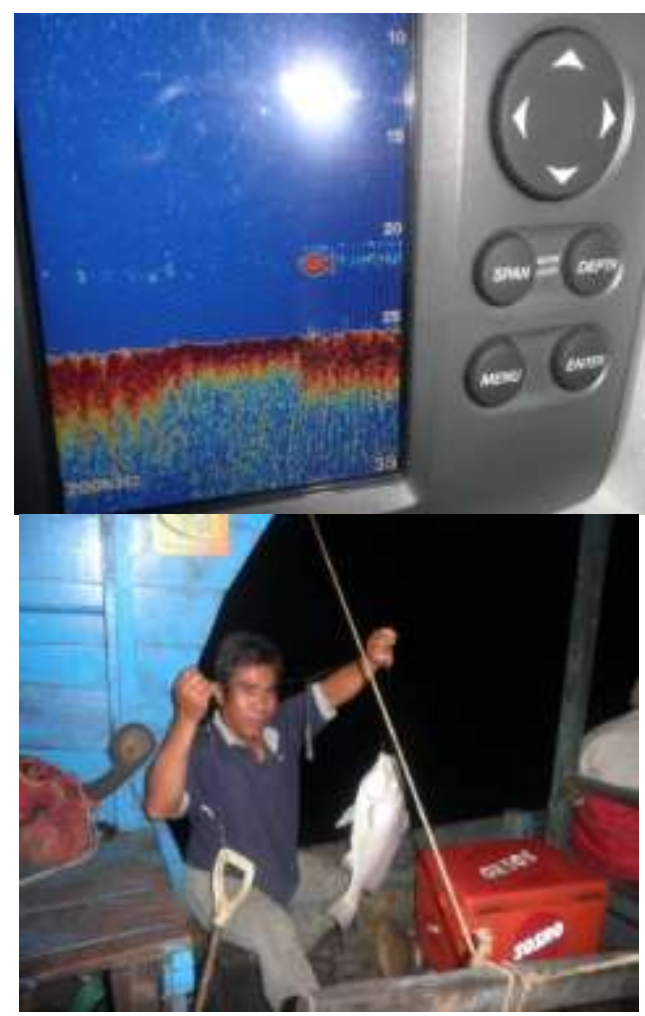

Gb. 16. Gambar ikan terekam fish finder Gb. 17. Ikan hasil tangkapan
Pada gambar 16 tampak gambar ikan yang terekam pada layar monitor, pada gambar cuma terekam 1 ekor ikan dan dasar laut kelihatan datar, pada posisi seperti ini peluang hasil tangkapan cenderung sedikit. Perlu dilakukan pemilihan lokasi lain yang kondisi dasar laut bergelombang (indicator adanya karang) dan ikan yang terekam monitor terlihat banyak, sehingga peluang hasil tangkapan juga lebih banyak. Pada gambar 6 ditampilkan hasil tangkapan berupa ikan karang dengan berat lebih kurang dua kilogram. Hasil tangkapan seperti inilah yang selalu diharapkan nelayan tradisional.

\subsection{Pengambilan Sampel Ikan}

Setelah dilakukan beberapa minggu pemasangan rumpon bersama nelayan, kemudian dilakukan pengambilan sampel. Pengambilan sampel bertujuan untuk mengetahui jenis ikan yang ada disekitar rumpon. Adapun gambar pengambilan sempel dapat dilihat pada gambar dibawah ini;

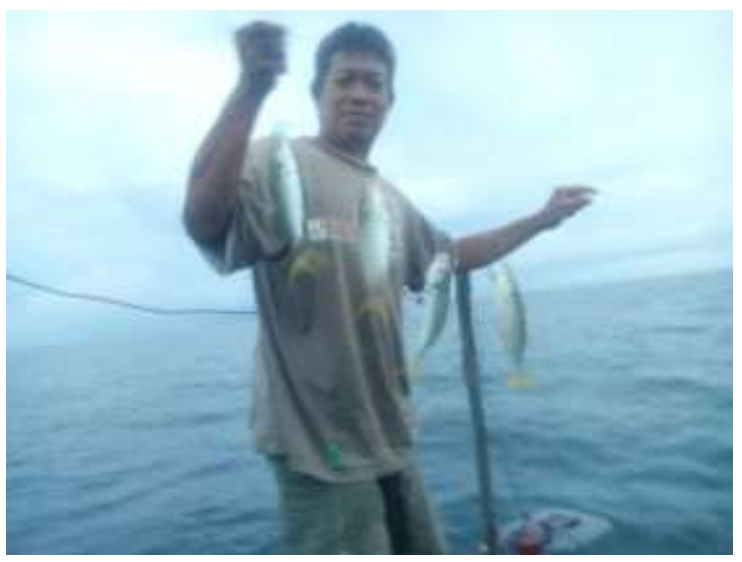

Gambar 18. Pengambil sampel ikan pada rumpon 


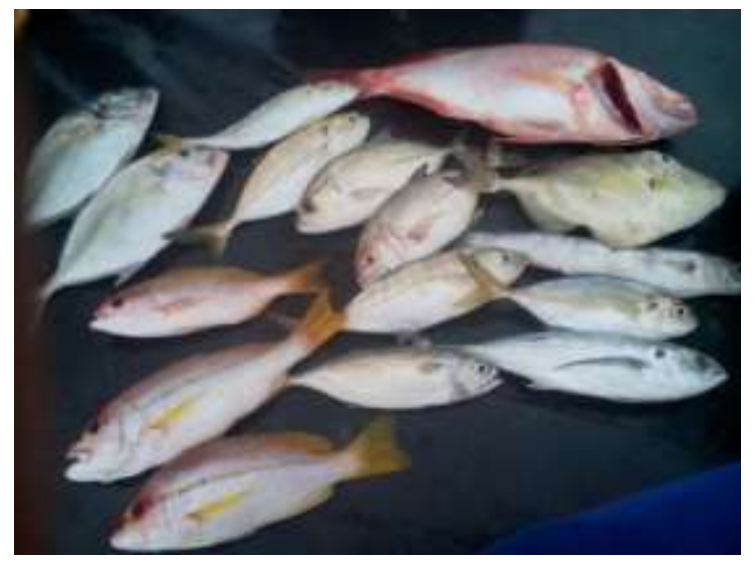

Gambar 19. Jenis Ikan yang ada disekitar rumpon

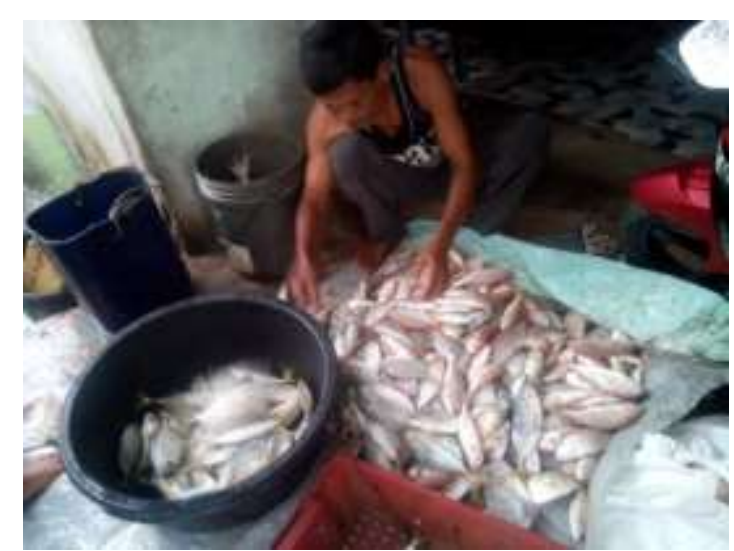

Gambar 20. Hasil tangkapan nelayan

\section{KESIMPULAN}

Kegiatan PKM dengan judul "Teknologi Rumpon Untuk Nelayan Tradisional di Kecamatan Pemangkat Kabupaten Sambas “ diharapkan dapat meningkatkan pendapatan nelayan tradisional di Pemangkat.

\section{UCAPAN TERIMAKASIH}

Ucapan terimakasi penulis sampaikan kepada Kemenristek Dikti yang telah memberikan bantu dana kegiatan Pengabdian Kepada Masayarakat dengan judul teknologi rumpon untuk nelayan tradisional di Kecamatan Pemangkat Kabupaten Sambas.

\section{DAFTAR PUSTAKA}

Sambas, B.P.S.S., 2013. Kabupaten Sambas dalam angka 2012. BPS, Sambas. 149p.

Handayani, B., 2013. Studi pendapatan penjala rumpon di Manggar Baru Balikpapan.J. IImu Perikanan Tropis, 18(2), pp.1-9.
Kurniawan, M.R., Setyohadi, D.D. and Bintoro, G.G., 2013. Pengaruh Pemasangan Rumpon Pada Musim Barat Terhadap Hasil Tangkapan Alat Tangkap Payang Di Perairan Tuban Jawa Timur.Jurnal Mahasiswa Pemanfaatan Sumberdaya Perikanan dan Kelautan, 1(1), pp.16-20.

Safitri, I.A., Rudiyanto, B., Nursalim, A. and Hariono, B., 2016. Uji Kinerja Smart Gried Fuel Cell Tipe Proton Exchange Membran (PEM) Dengan Penmbahan Hidrogen. Jurnal Ilmiah Inovasi, 16(1).

Suwarsih. 2012. Rumpon Sebagai daerah Penangkapan Ikan. ejournal.unirow.ac.id. Diakses pada tanggal 2 Mei 2016. 